\title{
Interpretation of nutrient-enrichment bioassays by looking at sub-populations in a marine bacterial community
}

\author{
Gro Anita Fonnes Flaten ${ }^{1, *}$, Tonje Castberg ${ }^{2}$, Tsuneo Tanaka ${ }^{1,3}$, T. Frede Thingstad ${ }^{1}$ \\ ${ }^{1}$ Department of Microbiology, University of Bergen, Jahnebakken 5, 5020 Bergen, Norway \\ ${ }^{2}$ Institute of Marine Research, Department of Coastal Zone, Flødevigen Marine Research Station, 4817 His, Norway \\ ${ }^{3}$ LOV-UMR7093, Station Zoologique, BP 28, 06234 Villefranche-sur-Mer, France
}

\begin{abstract}
Nutrient-enrichment bioassays represent one frequently applied way of assessing the nutrient status of natural bacterial communities. Interpretation of these is normally based on gross community responses like total bacterial abundance or production. To add more resolution, we supplemented these gross community measures with bacterial community analysis using DGGE and FCM. Sub-samples from a fjord on the Norwegian west coast were incubated in triplicate assay bottles spiked with organic $\mathrm{C}$ (glucose), mineral $\mathrm{N}\left(\mathrm{NH}_{4} \mathrm{Cl}\right)$ and $\mathrm{P}\left(\mathrm{KH}_{2} \mathrm{PO}_{4}\right)$ in all 8 possible combinations. Both 24 and $72 \mathrm{~h}$ after nutrient addition, ${ }^{3} \mathrm{H}$-leucine incorporation in all cultures enriched with organic $\mathrm{C}$ (alone or in combinations with $\mathrm{N}$ and $\mathrm{P}$ ) was higher than for all non-C treatments, consistent with an interpretation of a C-limited bacterial community in the original sample. FCM demonstrated an increase in the high-DNA fraction of the bacterial community, indicating either a growth of these as a subpopulation, or a shift from low to high DNA of bacteria activated by the added glucose. DGGE analysis revealed different band patterns in C-enriched cultures compared to non-C treatments, indicating that only one or a few sub-populations responded with a higher growth rate to the $\mathrm{C}$ substrate given. The conclusion from gross community responses should therefore be interpreted only with care as indicating $\mathrm{C}$-limitation for all sub-populations in the bacterial community.
\end{abstract}

KEY WORDS: Bacteria · Nutrient limitation · Bioassay $\cdot$ DGGE

\section{INTRODUCTION}

The dissolved fractions of the marine pelagic environment contain larger amounts of organic $\mathrm{C}$ than living organisms (Copin-Montegut \& Avril 1993, Ducklow et al. 1995, Williams 1995, Børsheim \& Myklestad 1997). This has accentuated the importance of understanding the mechanisms that control bacterial consumption of this material. Although an important role of heterotrophic bacteria in the pelagic $\mathrm{C}$ cycle has been recognized for many years (Pomeroy 1974, Williams 1981, Azam et al. 1983) the question of how resources (bottom-up) and predator factors (top-down) control and limit the development of bacterial populations is still not completely answered.
We focus here on the bottom-up mechanisms Growth of heterotrophic bacteria can be controlled in different manners by mineral nutrients or by $\mathrm{C}$ availability. Both cases have been suggested to occur both from observations (e.g. Rivkin \& Anderson 1997) and from theoretical models (Thingstad \& Lignell 1997). It has also been shown that addition of micronutrients, e.g. $\mathrm{Fe}$, can give a response in bacterial growth (Church et al. 2000, Hutchins et al. 2001).

The assessment of bacterioplankton control by nutrient availability in a natural sample is far from trivial, partly since any set-up will have to be designed from the conceptual understanding one might have of limitation in a mixed community, and partly because there is no single method that seems to give a clear-cut 
answer in all situations. There are 3 main approaches that have been used to assess nutrient limitation; (1) to infer limitation from measured concentrations of potentially limiting substrates, (2) to assess physiological properties of cells in sample from bulk (Paasche \& Erga 1988, Berdalet et al. 1996), from elemental composition of single cells (e.g. Fagerbakke et al. 1996), from ectoenzyme activities (e.g. Sala et al. 2001), or from specific antibodies against a protein which marks the P status of picoplankton (Scanlan et al. 1997), and (3) bioassay experiments based on the assumption that releasing the limitation(s) will induce a measurable response (e.g. Thingstad et al. 1993, Pomeroy et al. 1995, Rivkin \& Anderson 1997, Zohary et al. 1998).

A nutrient-enrichment bioassay is in this context meant as a sample from nature, divided into subsamples amended with inorganic nutrients $(\mathrm{N}, \mathrm{P})$, organic nutrients (C), or micronutrients (e.g. Fe) alone and in combinations. The response is measured after incubation. This kind of assessment of limitation has been widely used both for bacterioplankton (Morris \& Lewis 1992, Schweitzer \& Simon 1995, Caron et al. 2000, Carlsson \& Caron 2001) and phytoplankton (e.g. Morris \& Lewis 1988, Jarvinen et al. 1999, Seppala et al. 1999, Caron et al. 2000, Chrzanowski \& Grover 2001) covering different marine and freshwater environments such as lakes in Massachusetts (Carlsson \& Caron 2001), the Mediterranean (Hagstrom et al. 2001, Sala et al. 2002), the California upwelling regime (Kirchman et al. 2000) and the Tuamotu Archipelago (Torreton et al. 2000). Modifications of this kind of bioassay have also been conducted regularly, e.g. as a dilution bioassay (Chrzanowski \& Grover 2001).

While often giving results that seem reasonable when interpreted in terms of the conceptual framework within which such experiments are designed, this is, in our experience, far from always the case, suggesting that our understanding of the physiological and ecological mechanisms responding to our manipulations (confinement, enrichment, and incubation) are incomplete.

None of the above mentioned bioassays have been supplemented with the denaturant gradient gel electrophoresis (DGGE) technique as well as flow cytometer (FCM) analysis to give detailed information at the sub-population level. To get a higher resolution of the response occurring in bioassays for bacterial limitation, we have supplemented the measurements of bacterial production with the higher resolution provided by DGGE and FCM analysis, in order to study the responses of a winter community of bacterioplankton from a Norwegian fjord to nutrient additions $(C, N, P)$.

Our results suggest that bioassay experiments, even when given an apparent clear answer in terms of stimulated bacterial production or net increase in total abundance, should only be interpreted with care as demonstrating the nature of the limiting substrate for all sub-populations of heterotrophic bacteria.

\section{MATERIALS AND METHODS}

Sampling site. Surface water was collected on November 9, 2000 from Raunefjorden $\left(60^{\circ} 16^{\prime} \mathrm{N}, 5^{\circ} 14^{\prime} \mathrm{E}\right)$, $15 \mathrm{~km}$ south of Bergen, on the western coast of Norway. The experiment was started within a few hours of sampling.

Experimental set-up. Acid-rinsed $250 \mathrm{ml}$ Pyrex glass bottles were filled with $200 \mathrm{ml}$ of seawater and enriched with nutrients in all combinations of $\mathrm{C}$ (glucose, $\left.100 \mu \mathrm{mol} \mathrm{C} \mathrm{l}{ }^{-1}\right), \mathrm{N}\left(\mathrm{NH}_{4} \mathrm{Cl}, 20 \mu \mathrm{mol} \mathrm{N} \mathrm{l^{-1 }}\right)$ and $\mathrm{P}$

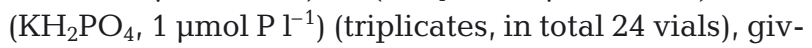
ing this series: control $(\mathrm{Co})$, carbon $(\mathrm{C})$, nitrogen $(\mathrm{N})$, phosphorous $(\mathrm{P})$, carbon and nitrogen $(\mathrm{CN})$, carbon and phosphorous (CP), nitrogen and phosphorous (NP) and carbon, nitrogen and phosphorous (CNP). A total of $5.13 \mu \mathrm{mol} \mathrm{N} \mathrm{l^{-1 }}$ and $0.39 \mu \mathrm{mol} \mathrm{P} \mathrm{l}{ }^{-1}$ were measured in comparable outer-part Norwegian fjord systems in November (Erga 1989). The samples were incubated in the dark at in situ temperature $\left(8^{\circ} \mathrm{C}\right)$ for $72 \mathrm{~h}$ and sampled at $0,24,48$ and $72 \mathrm{~h}$. We did not filter the water to get rid of grazers because we wanted to avoid any potential release of nutrients during filtration. Dark incubation was chosen to minimize phytoplankton competition for nutrients in this experiment, which was focusing on bacterial responses.

Bacterial production. Bacterial production was measured by uptake of tritiated leucine (Kirchman et al. 1985), as modified by Smith \& Azam (1992), and the data are presented as cumulated bacterial production (area below the leucine incorporation curve). The final concentration of tritiated leucine was $60 \mathrm{nM}$.

PCR-DGGE. DGGE analysis of the bacterial community composition was done as described in Larsen et al. (2001), except that a BioRad DGGE unit was used (Biorad, Dcode System, Hercules).

DGGE gel images were scanned to TIFF files and analysed in a gel-analysis program, Gel (S. Norland, Dept. of Microbiology, University of Bergen). The program detects the presence or absence of bands in individual lanes and converts the gel-image into a binary data matrix. The distance between samples (i.e. lanes on the gels) was calculated as simple matching distances and the cluster analysis was performed using a complete link algorithm. Band intensities were not taken into account in this analysis.

FCM. All analyses were performed with a FACSCalibur FCM (Becton Dickinson) equipped with an air-cooled laser providing $15 \mathrm{~mW}$ at $488 \mathrm{~nm}$ and with the standard filter set-up. Enumeration of bacteria 
was performed on samples fixed with glutaraldehyde for $30 \mathrm{~min}$ at $4^{\circ} \mathrm{C}$, followed by freezing in liquid nitrogen and storage at $-70^{\circ} \mathrm{C}$ until further analysis. The FCM instrumentation and the remaining methodology followed the recommendations of Marie et al. (1999).

Statistical analysis. We performed $t$-tests which were normally assuming unequal variances on mean values of bacterial production and bacterial abundance. A $t$-test assuming equal variance was performed comparing bacterial abundance data from 0 and $24 \mathrm{~h}$ because of 1 single measurement at $0 \mathrm{~h}$.

\section{RESULTS}

\section{FCM analysis of the bacterial community}

While total bacterial abundance did not change significantly ( $t$-test, $p=0.05$ ) in any of the treatments between 0 and $24 \mathrm{~h}$, an increase was found in all treatments with glucose added after 48 and $72 \mathrm{~h}$. In bottles receiving $\mathrm{N}$ and $\mathrm{P}$, alone or in combinations, cell abundance remained stable and similar to the control with no nutrients added (Fig. 1A). The bacterial abundance in treatments with glucose additions was significantly higher than in the treatments without $\mathrm{C}$ at 48 and $72 \mathrm{~h}(t$-test, $\mathrm{p}=0.05)$. An approximate doubling in response was found in treatments receiving $\mathrm{P}$ in addition to $\mathrm{C}$ ( $\mathrm{CP}$ and $\mathrm{CNP}$ compared to the response in $\mathrm{C}$ and $\mathrm{CN}$ ), indicating an additional effect of $\mathrm{P}$ when supplied together with the $\mathrm{C}$ source. The bacterial abundance in treatments with both $\mathrm{C}$ and $\mathrm{P}$ $(\mathrm{CP}, \mathrm{CNP})$ were significantly higher than in the treatments with $\mathrm{C}$ and no $\mathrm{P}(\mathrm{C}, \mathrm{CN})$ at $72 \mathrm{~h}$ ( $t$-test, $\mathrm{p}=$ 0.05).

In the FCM, 2 bacterial populations could be discriminated based on side scatter (SSC) and green fluorescence (FL1) (Fig. 1B). The frames of discrimination were kept fixed through all the measurements. Extracting the low DNA (LDNA) and high DNA (HDNA) counts for all treatments and sampling times (Fig. 1C) reveals that most of the response occurred in the HDNA-fraction.

\section{Bacterial production}

Cumulated bacterial production after 72 h (Fig. 2) gave a picture similar to that of bacterial abundance. It was significantly higher in the $\mathrm{C}$-enriched cultures compared to the cultures not given $\mathrm{C}(t$-test, $\mathrm{p}=$ 0.05). The additional effect of $P$ addition cannot be documented in the cumulated bacterial production data.
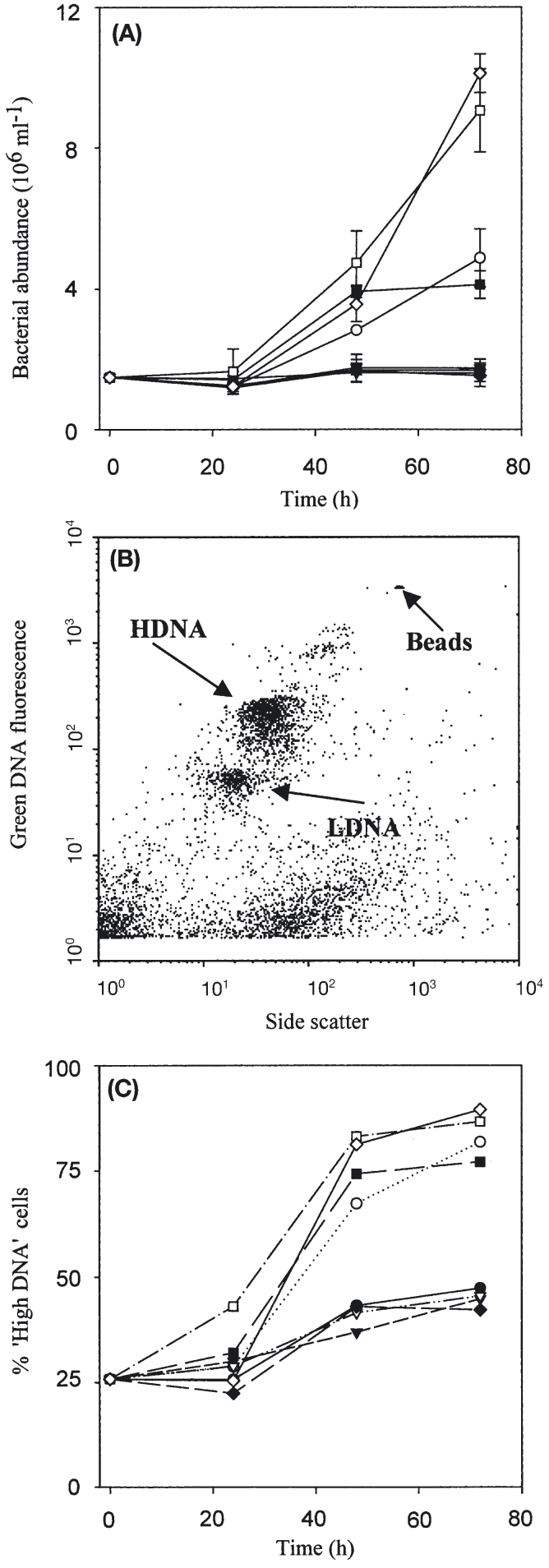

Fig. 1. (A) Bacterial numbers (mean $\pm \mathrm{SD}$ ) counted by flow cytometry (FCM) in the different enrichments; C (O), N ( $)$, P $(\nabla), \mathrm{CN}(\bullet), \mathrm{CP}(\square), \mathrm{NP}(\bullet) \mathrm{CNP}(\diamond)$ and in the control $(\bullet)$. (B) Biparametric FCM plot of characteristic populations. Side scatter (SSC) versus green fluorescence (FL1) showing bacterial sub populations high DNA (HDNA) and low (LDNA) DNA. See 'Results' for detailed descriptions. (C) Percentage of bacteria with HDNA content counted by FCM in the different enrichments; symbols as shown in (A) 


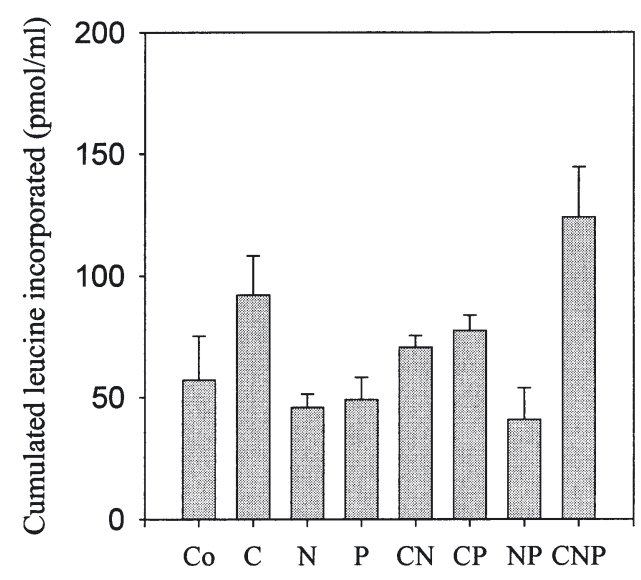

Fig. 2. Cumulated leucine incorporated $(+\mathrm{SD})$ after $72 \mathrm{~h}$ in the enriched microcosms. Co: control

\section{PCR-DGGE}

The DGGE profile of the untreated sample $(0 \mathrm{~h})$ had at least 14 easily distinguishable bands (Fig. 3A). The position of the bands will be referred to as Position $x$ from the ruler indicated in Fig. 3A. We emphasise that although DGGE is not a quantitative method, relative band-intensity variation reflects to some extent the relative abundance of different bacterial groups (Bruggemann et al. 2000, McCaig et al. 2001, Sekiguchi et al. 2001). Twenty-four hours after nutrient addition, the band present at $0 \mathrm{~h}$ in Position 6 had become dominant (in terms of intensity) in all treatments, control included. This band also remained dominant after $48 \mathrm{~h}$. In addition there is 1 very clear and dominant band appearing in all the cultures given C (Position 7.4), clearly visible at both 24 and $48 \mathrm{~h}$ after addition. In the $\mathrm{C}$-enriched cultures, an extra band appeared in Position 8.2 at 48 h.

The cluster analysis (Fig. 3B) demonstrates how, after $48 \mathrm{~h}$, all $\mathrm{C}$-amended treatments have similar banding patterns at the most distant point from $0 \mathrm{~h}$. Forty-eight hour samples with $\mathrm{N}$ or $\mathrm{P}$ added cluster more closely to the control.

\section{DISCUSSION}

Bacterial abundance and production data give a response pattern indicating a situation in the collected sample characterized by C-limitation of the bacteria. In the present case, this was the response expected as the sample was collected in November, a season that at this latitude is characterised by low-light conditions, poor phytoplankton growth, and free mineral nutrients. Poor phytoplankton growth would be expected to imply the combination of the minimal competition for mineral nutrients with low production of degradable organic substrates for the heterotrophic bacteria, conditions which would jointly drive the system in the direction of C-limited bacterial growth. Our assay indicated that bacteria experienced a primary C-limitation and secondary P-limitation, in the sense that $\mathrm{P}$ had additional effect once $C$ had been supplied.

Addition of $\mathrm{C}$ and $\mathrm{CP}$ had an apparent effect on the bacterial community composition as seen on the DGGE gel after $24 \mathrm{~h}$, while an easily identifiable response in cell abundance and bacterial production required $48 \mathrm{~h}$ incubation. Although providing the anticipated result, $48 \mathrm{~h}$ is an uncomfortably long incubation time when the objective is to test conditions in the sampled water body. Some investigations, such as those in the NW Mediterranean (Thingstad et al. 1998), demonstrated a measurable effect in bioassays after only a few hours of incubation. Our data does not give an unequivocal answer to what mechanisms caused the delay in the present case. Several reasons for such differences in the delay of an observable response can be hypothesized: low maximum bacterial growth rate at the low temperature of the present sample, a particularly rapid response when thymidine incorporation is used as the test parameter in an environment where bacteria are P-limited, such as in the Mediterranean case studied by Thingstad et al. (1998), or a response restricted in the present case to only a small subpopulation of the bacterial community. Our results from both FCM and DGGE analysis are consistent with the last of these hypotheses: the bands at Positions 7.4 and 8.2 may initially represent a small fraction of the total community, but supplied with glucose they respond rapidly, and if not already members of the HDNA population, they become so once given glucose, and grow sufficiently more rapid than the others to become dominant within $48 \mathrm{~h}$. Eilers et al. (2000) showed similar results when studying the succession of marine, pelagic bacteria during enrichment. Incubation resulted in rapid community shifts towards typical culturable genera. Our observation can also be supported by Fisher et al. (2000). They found evidence through analysis of ribosomal intergenic spacer PCR fragments that resource additions may have stimulated the growth of different subsets of organisms across the treatments. It is not known if this truly indicated different bacterial populations responding to various resource additions or if this is a result of PCR bias. Note that such an interpretation of our DGGE analysis is based on the assumption that intensity of DGGE bands to a certain extent reflects the relative, not absolute, abundance of corresponding bacterial populations. This only leads to a conclusion of a difference in growth rates between bacterial ribotypes after addition, and cannot be used 
(A)

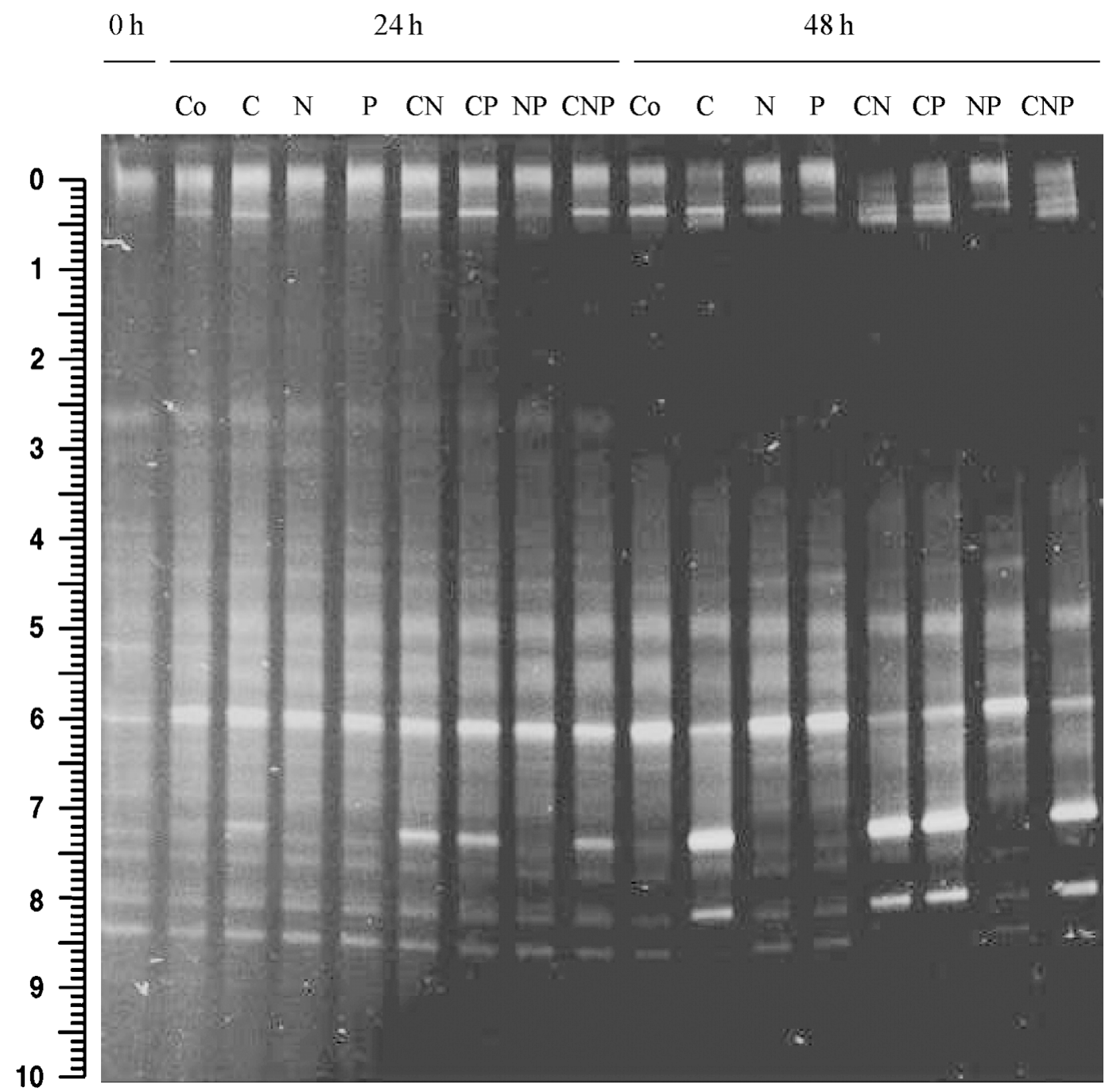

(B)

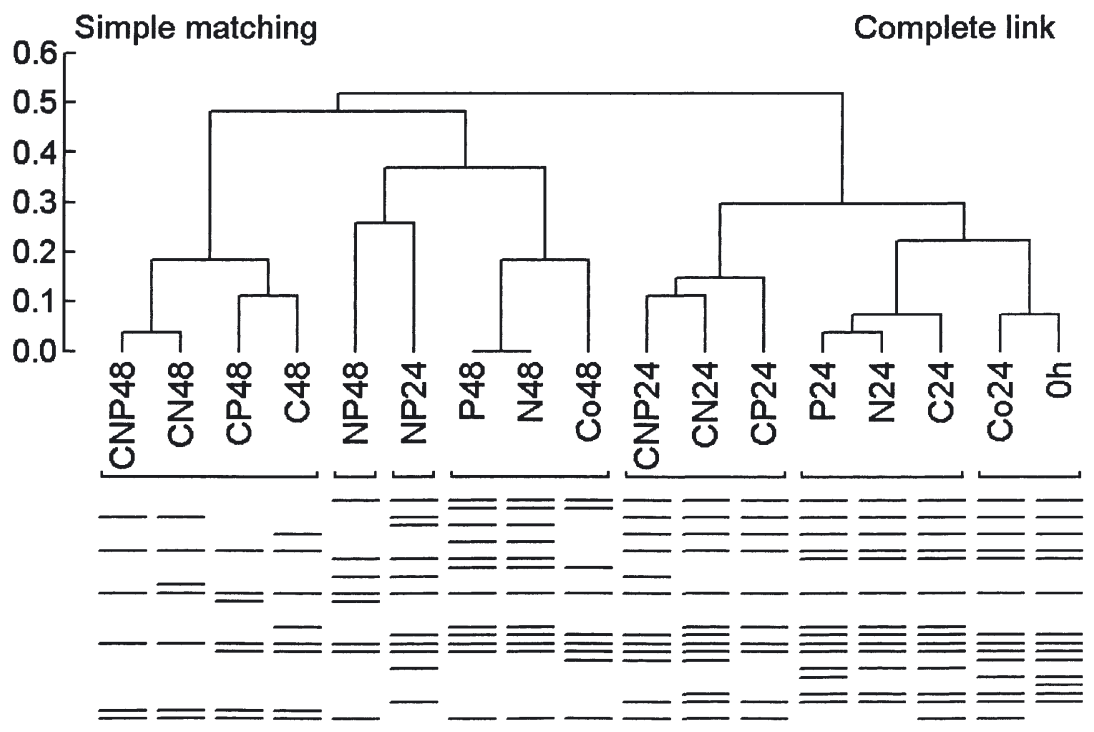

Fig. 3. (A) DGGE profiles from analysis of 16S rDNA. (B) Dendrogram made from the band pattern on the DGGE gel by simple matching and complete link algorithms. Co: control 
to rule out a possible (but small) response in the other ribotypes.

A surprising aspect of the bioassay is that the bacterial numbers increased by a factor of up to 6.8 , whereas the cumulated bacterial production increased by a factor of 2.2 only. Generally the contrary is observed, i.e. the bacterial production rate per cell increases (Massana et al. 2001). The large increase in bacterial abundance may suggest that a part of the C-responding bacteria escape grazing, at least over the timescale studied. Grazers have been shown to be selecting for particular bacterial ribotypes (Pernthaler et al. 1997, Lebaron et al. 2001, Simek et al. 2001).

In an ideal bioassay, there should be no effects of the incubation itself; the only perturbation of the system should be the nutrient additions. As shown by the cluster analysis (Fig. 3B), the DGGE patterns in the control culture drifted away from that at $0 \mathrm{~h}$, suggesting that our incubation conditions, including confinement in $250 \mathrm{ml}$ glass bottles, had an effect on bacterial community composition, either directly or indirectly via, for example, an incubation effect on the community of bacterial predators. At the coarser level of bacterial abundance and bacterial production, however, changes in the controls were small compared to those induced by glucose additions.

Nutrient enrichment bioassays have been performed in a variety of ways. This bioassay was performed with unfiltered whole water. The possible effects of filtering the water sample are not easy to control. Organisms may break (Ferguson et al. 1984) and it would be difficult to account for the subsequent release of nutrients. It may also influence the composition of the bacterial community by removal of large filamentous cells and most of the particle-attached cells (Delong et al. 1993, Acinas et al. 1999). With no filtration, predators may influence the bacterioplankton community by grazing and recycling. A response in the form of a net increase in abundance may be reduced, but limiting conditions may, in principle, also change if nutrient supply by recycling is removed. No predator-prey succession is apparent from the development of bacterial abundance. The enriched cultures were incubated in the dark to avoid the competition for nutrients from phytoplankton. For instance Carlsson \& Caron (2001) chose moderate light in order not to minimize the potential competitive relationship between bacteria and phytoplankton for mineral resources. There is a possibility that our dark incubations may have prevented phytoplankton synthesis and potentially reduced the release of labile DOC compounds.

Different nutrient status has been shown to cause differences in virus production both in cyanobacteria (Wilson et al. 1996) and in microalgae (Bratbak et al. 1993, Jacquet et al. 2002); such aspects may also influ- ence the outcome of the bioassay. Likewise, increased bacterial production has been shown to enhance increased viral activity (Heldal \& Bratbak 1991, Maranger \& Bird 1995). Impact by viral activity is an aspect that to our knowledge has not been dealt with in this kind of bioassay. If viruses control bacterial diversity as hypothesized (Thingstad 2000), incubation effects on viruses could effect the DGGE patterns. Virus and bacterial successions can take out one species and make room for another one, making the assessment of the nutrient limitation situation even harder based on such a bioassay.

The C source we used, glucose, is by far the most common source used in enrichment experiments of this kind (e.g. Elser et al. 1995, Gurung \& Urabe 1999). However, bacteria in the aquatic (marine) environment encounter a diverse $\mathrm{C}$ substrate in the form of dissolved organic $\mathrm{C}$ and they can process a wide variety of organic matter (Martinez et al. 1996). Considering the heterogeneity of the $\mathrm{C}$ substrate in natural environments, it is likely that organic matter can exert a strong selective force (Pinhassi 1999), a factor which is not taken into account in a bioassay like ours with only one $\mathrm{C}$ source.

This experiment shows that some of the bacteria experience C-limitation and give the results that we are often interpreting as a common nutrient limitation for all the bacteria present. This experiment gives a higher resolution and shows that one has to be careful to include all the species present in such a conclusion.

Acknowledgements. This work was financed by the University of Bergen, the EC through contract EVK3-CT-2001-00049 'DANLIM', and by Bergen Marine Food Chain Research Infrastructure.

\section{LITERATURE CITED}

Acinas SG, Anton J, Rodriguez-Valera F (1999) Diversity of free-living and attached bacteria in offshore western Mediterranean waters as depicted by analysis of genes encoding 16S rRNA. Appl Environ Microb 65:514-522

Azam F, Fenchel T, Field JG, Gray JS, Meyer-Reil LA, Thingstad TF (1983) The ecological role of water-column microbes in the sea. Mar Ecol Prog Ser 10:257-263

Berdalet E, Marrase C, Estrada M, Arin L, MacLean ML (1996) Microbial community responses to nitrogen- and phosphorus-deficient nutrient inputs: Microplankton dynamics and biochemical characterization. J Plankton Res 18:1627-1641

Bratbak G, Egge JK, Heldal M (1993) Viral mortality of the marine alga Emiliania huxleyi (Haptophyceae) and termination of algal blooms. Mar Ecol Prog Ser 93:39-48

Bruggemann J, Stephen JR, Chang YJ, Macnaughton SJ, Kowalchuk GA, Kline E, White DC (2000) Competitive PCR-DGGE analysis of bacterial mixtures: an internal standard and an appraisal of template enumeration accuracy. J Microbiol Methods 40:111-123 
Børsheim K, Myklestad S (1997) Dynamics of DOC in the Norwegian Sea inferred from monthly profiles collected during 3 years at $66^{\circ} \mathrm{N}, 2^{\circ} \mathrm{E}$. Deep-Sea Res Part I 44:593-601

Carlsson P, Caron DA (2001) Seasonal variation of phosphorus limitation of bacterial growth in a small lake. Limnol Oceanogr 46:108-120

Caron DA, Lim EL, Sanders RW, Dennett MR, Berninger UG (2000) Responses of bacterioplankton and phytoplankton to organic carbon and inorganic nutrient additions in contrasting oceanic ecosystems. Aquat Microb Ecol 22: 175-184

Chrzanowski TH, Grover JP (2001) Effects of mineral nutrients on the growth of bacterio- and phytoplankton in two southern reservoirs. Limnol Oceanogr 46:1319-1330

Church MJ, Hutchins DA, Ducklow HW (2000) Limitation of bacterial growth by dissolved organic matter and iron in the Southern Ocean. Appl Environ Microbiol 66:455-466

Copin-Montegut G, Avril B (1993) Vertical distribution and temporal variation of dissolved organic carbon in the North-Western Mediterranean Sea. Deep-Sea Res 40: 1963-1972

Delong EF, Franks DG, Alldredge AL (1993) Phylogenetic diversity of aggregate-attached vs free-living marine bacterial assemblages. Limnol Oceanogr 38:924-934

Ducklow H, Carlson C, Bates N, Knap A, Michaels A (1995) Dissolved organic carbon as a component of the biological pump in the North Atlantic Ocean. Phil Trans R Soc Lond B 1324:161-167

Eilers H, Pernthaler J, Amann R (2000) Succession of pelagic marine bacteria during enrichment: a close look at cultivation-induced shifts. Appl Environ Microbiol 66:4634-4640

Elser JJ, Stabler LB, Hassett RP (1995) Nutrient limitation of bacterial growth and rates of bacterivory in lakes and oceans: a comparative study. Aquat Microb Ecol 9: $105-110$

Erga SR (1989) Ecological studies on the phytoplankton of Boknafjorden, Western Norway. 1. The effect of water exchange processes and environmental-factors on temporal and vertical variability of biomass. Sarsia 74:161-176

Fagerbakke KM, Heldal M, Norland S (1996) Content of carbon, nitrogen, oxygen, sulfur and phosphorus in native aquatic and cultured bacteria. Aquat Microb Ecol 10: $15-27$

Ferguson RL, Buckley EN, Palumbo A (1984) Response of marine bacterioplankton to differential filtration and confinement. Appl Environ Microbiol 47:49-55

Fisher MM, Klug JL, Lauster G, Newton M, Triplett EW (2000) Effects of resources and trophic interactions on freshwater bacterioplankton diversity. Microb Ecol 40:125-138

Gurung TB, Urabe J (1999) Temporal and vertical difference in factors limiting growth rate of heterotrophic bacteria in Lake Biwa. Microb Ecol 38:136-145

Hagstrom A, Pinhassi J, Zweifel UL (2001) Marine bacterioplankton show bursts of rapid growth induced by substrate shifts. Aquat Microb Ecol 24:109-115

Heldal M, Bratbak G (1991) Production and decay of viruses in aquatic environments. Mar Ecol Prog Ser 72:205-212

Hutchins DA, Campbell BJ, Cottrell MT, Takeda S (2001) Response of marine bacterial community composition to iron additions in three iron-limited regimes. Limnol Oceanogr 46:1535-1545

Jacquet S, Heldal M, Iglesias-Rodriguez D, Larsen A, Wilson W, Bratbak G (2002) Flow cytometric analysis of an Emiliana huxleyi bloom terminated by viral infection. Aquat Microb Ecol 27:111-124

Jarvinen M, Salonen K, Sarvala J, Vuorio K, Virtanen A (1999) The stoichiometry of particulate nutrients in Lake Tan- ganyika - implications for nutrient limitation of phytoplankton. Hydrobiologia 407:81-88

Kirchman DL, K'Nees E, Hodson R (1985) Leucine incorporation and its potential as measure of protein synthesis by bacteria in natural aquatic samples. Appl Environ Microbiol 49:599-607

Kirchman DL, Meon B, Cottrell MT, Hutchins DA, Weeks D, Bruland KW (2000) Carbon versus iron limitation of bacterial growth in the California upwelling regime. Limnol Oceanogr 45:1681-1688

Larsen A, Castberg T, Sandaa RA, Brussaard CPD and 6 others (2001) Population dynamics and diversity of phytoplankton, bacteria and viruses in a seawater enclosure. Mar Ecol Prog Ser 221:47-57

Lebaron P, Servais P, Troussellier M, Courties C and 7 others (2001) Microbial community dynamics in Mediterranean nutrient-enriched seawater mesocosms: changes in abundances, activity and composition. FEMS Microbiol Ecol 34: $255-266$

Maranger R, Bird DF (1995) Viral abundance in aquatic systems - a comparison between marine and fresh-waters. Mar Ecol Prog Ser 121:217-226

Marie D, Brussaard CPD, Partensky F, Vaulot D (1999) Enumeration of phytoplankton, bacteria, and viruses in marine samples. In: Robinson JP, Darzynkiewicz Z, Dean $\mathrm{PN}$, Orfao A and 4 others (eds) Current protocols in cytometry. John Wiley \& Sons, Chichester, p 11.11.11-11.11.15

Martinez J, Smith DC, Steward GF, Azam F (1996) Variability in ectohydrolytic enzyme activities of pelagic marine bacteria and its significance for substrate processing in the sea. Aquat Microb Ecol 10:223-230

Massana R, Pedros-Alio C, Casamayor EO, Gasol JM (2001) Changes in marine bacterioplankton phylogenetic composition during incubations designed to measure biogeochemically significant parameters. Limnol Oceanogr 46: $1181-1188$

McCaig AE, Glover LA, Prosser JI (2001) Numerical analysis of grassland bacterial community structure under different land management regimens by using $16 \mathrm{~S}$ ribosomal DNA sequence data and denaturing gradient gel electrophoresis banding patterns. Appl Environ Microb 67: $4554-4559$

Morris DP, Lewis WM (1988) Phytoplankton nutrient limitation in Colorado mountain lakes. Freshw Biol 20:315-327

Morris DP, Lewis WM (1992) Nutrient limitation of bacterioplankton growth in Lake Dillon, Colorado. Limnol Oceanogr 37:1179-1192

Paasche E, Erga SR (1988) Phosphorous and nitrogen limitation of phytoplankton in the inner Oslofjord (Norway). Sarsia 73:229-243

Pernthaler J, Posch T, Simek K, Vrba J, Amann R, Psenner R (1997) Contrasting bacterial strategies to coexist with a flagellate predator in an experimental microbial assemblage. Appl Environ Microbiol 63:596-601

Pinhassi J (1999) Population dynamics in marine bacterioplankton. PhD thesis, Umea University, Sweden

Pomeroy LR (1974) The ocean's food web: a changing paradigm. BioScience 24:499-504

Pomeroy LR, Sheldon JE, Sheldon WM, Peters F (1995) Limits to growth and respiration of bacterioplankton in the Gulf of Mexico. Mar Ecol Prog Ser 117:259-268

Rivkin RB, Anderson MR (1997) Inorganic nutrient limitation of oceanic bacterioplankton. Limnol Oceanogr 42:730-740

Sala MM, Karner M, Arin L, Marrase C (2001) Measurement of ectoenzyme activities as an indication of inorganic nutrient imbalance in microbial communities. Aquat Microb Ecol 23:301-311 
Sala MM, Peters F, Gasol JM, Pedros-Alio C, Marrase C, Vaque D (2002) Seasonal and spatial variations in the nutrient limitation of bacterioplankton growth in the northwestern Mediterranean. Aquat Microb Ecol 27: 47-56

Scanlan DJ, Silman NJ, Donald KM, Wilson WH, Carr NG, Joint I, Mann NH (1997) An immunological approach to detect phosphate stress in populations and single cells of photosynthetic picoplankton. Appl Environ Microb 63: $2411-2420$

Schweitzer B, Simon M (1995) Growth limitation of planktonic bacteria in a large mesotrophic lake. Microb Ecol 30: 89-104

Sekiguchi H, Tomioka N, Nakahara T, Uchiyama H (2001) A single band does not always represent single bacterial strain. Biotechnol Lett 23:1205-1208

Seppala J, Tamminen T, Kaitala S (1999) Experimental evaluation of nutrient limitation of phytoplankton communities in the Gulf of Riga. J Mar Syst 23:107-126

Simek K, Pernthaler J, Weinbauer MG, Hornak K, Dolan JR, Nedoma J, Masin M, Amann R (2001) Changes in bacterial community composition and dynamics and viral mortality rates associated with enhanced flagellate grazing in a mesoeutrophic reservoir. Appl Environ Microb 67: $2723-2733$

Smith DC, Azam F (1992) A simple, economical method for measuring bacterial protein synthesis in sea water using 3H-leucine. Mar Microb Food Webs 6:107-114

Thingstad TF (2000) Elements of a theory for the mechanisms controlling abundance, diversity, and biogeochemical role

Editorial responsibility: John Dolan,

Villefranche-sur-Mer, France of lytic bacterial viruses in aquatic systems. Limnol Oceanogr 45:1320-1328

Thingstad TF, Lignell R (1997) Theoretical models for the control of bacterial growth rate, abundance, diversity and carbon demand. Aquat Microb Ecol 13:19-27

Thingstad TF, Skjoldal EF, Bohne RA (1993) Phosphorous cycling and algal-bacterial competition in Sandsfjord, Western Norway. Mar Ecol Prog Ser 99:239-259

Thingstad TF, Zweifel UL, Rassoulzadegan F (1998) P limitation of heterotrophic bacteria and phytoplankton in the northwest Mediterranean. Limnol Oceanogr 43:88-94

Torreton JP, Talbot V, Garcia N (2000) Nutrient stimulation of bacterioplankton growth in Tuamotu atoll lagoons. Aquat Microb Ecol 21:125-137

Williams PJL (1981) Incorporation of microheterotrophic processes into the classical paradigm of the planktonic food web. Kiel Meeresforsch Sonderh 5:1-28

Williams PJL (1995) Evidence for the seasonal accumulation of carbon-rich dissolved organic material, its scale in comparison with changes in particulate material and the consequential effect on net $\mathrm{C} / \mathrm{N}$ assimilation ratios. Mar Chem 51:17-29

Wilson WH, Carr NG, Mann NH (1996) The effect of phosphate status on the kinetics of cyanophage infection in the oceanic cyanobacterium Synechococcus sp WH7803. J Phycol 32:506-516

Zohary T, Brenner S, Krom MD, Angel DL, Kress N, Li WKW, Neori A, Yacobi YZ (1998) Buildup of microbial biomass during deep winter mixing in a Mediterranean warm-core eddy. Mar Ecol Prog Ser 167:47-57

Submitted: September 23, 2002; Accepted: January 23, 2003 Proofs received from author(s): July 23, 2003 